Phys. Comm.3(1)(2019) 10-20
Physics Communication
UNNES

\title{
Phenomenon of Buying and Selling as Bridging Analogy of Learning Work and Energy
}

\author{
Eka Desianna ${ }^{凶}$, Sunyoto Eko Nugroho, Ellianawati \\ Pascasrjana, Universitas Negeri Semarang, Indonesia
}

\begin{abstract}
Article Info
Article History:

Submitted:

August, 22018

Accepted:

September, 52018

Published:

September, 52018

Keywords:

Bridging analogy,

Phenomenon of buying and

selling, Brain based

learning, Work and energy.

Abstract

Effective physics learning can be designed by recognizing students' difficulties in understanding physics concepts. Students build the concept through experience gained from the environment, so that they unconsciously have the concept in accordance with the understood. Students still have difficulty distinguishing work and energy definitions in physics and in everyday life. The concept of work and energy can be understood by students if students have good analogy skills. The Brain Based Learning (BBL) model through analogy facilitates learning to improve students' thinking ability analogy. The buying and selling analogy is used to relate concepts that students have understood (source problems) to the concept of work and energy as learning goals (target problems). Quasi-experimental learning is applied to determine the analogy of students. Data were analyzed from the achievement of analogy ability test results before and after learning. The success rate of mastering students' analogy abilities is analyzed from the stages of analogy in solving problems. Achievement of pretest and posttest scores of students 'analogy abilities shows that the BBL model through buying and selling analogy can improve students' analogy skills. The average achievement of students' analogy skills at the stage of generating the analogy includes good criteria, evaluating the analogy relations stage including good criteria, understanding the analogy case stage including good criteria, and at the transfering findings, including not good criteria. The results of the analogy ability show that the BBL model through the analogy of buying and selling gives positive results on the ability of students' analogy.
\end{abstract}

\footnotetext{
Alamat korespondensi:

Physics Eduction Pascasarjana Universitas Negeri Semarang

E-mail: ikade08@gmail.com
} 


\section{INTRODUCTION}

Physics is not just a knowledge of mathematical formulas and concepts that students must learn, but also contains an understanding of the concept to be applied in solving problems. The lack of understanding of the concept of physics is the cause of students not being able to solve the problems faced in learning physics. The process of learning physics should emphasize the provision of direct experience to develop students' competencies in exploring and understanding the natural surroundings scientifically. The physical problem solving that is faced can be solved if students have good analogy abilities. Prihartanti et al. (2017) revealed that the application of analogy in learning can be used to solve problems with the knowledge already possessed.

Analogy is one of the alternative strategies in learning physics in explaining a concept. Analogy helps students build an understanding of previous known concepts, concepts that are often complex and abstract from well-known concepts (Fathurohman, 2014). Analogy is required primarily on teaching concepts beyond the reach of the five senses. Teaching the concept requires visual observation tools. Teaching concepts that require learning aids include concepts on the atomic scale (microscopic) such as electron dynamics and macroscopic phenomena such as solar system concept.

Physics studies on work and energy concepts in high school has a wide scope and widely used in everyday life.. The concept of work and energy is complex and abstract because it contains interrelated concepts, so that there are may be misconceptions (Masita et al., 2015). Previous research has revealed that students still have difficulty in understanding the concept of work and energy.

Suana's research (2014) in uncovering misconceptions on the concept of mechanics found that matter of work and energy experienced the highest misconception. Students' difficulties among students are difficult to distinguish between the concept of force, mass and weight (Hasim, 2011). Barniol \& Zavala (2014) also found that students are confused to determine the work performed by certain force components. Students also experience difficulties in using energy conservation laws (Dalaklioglu et al., 2015) and difficulties in understanding the energy of systems in which they comprise several objects (Singh \& Schunn, 2009).

Physics exam questions are mostly in the form of questions that prioritize mathematical calculations, few problems about understanding definitions, analyzing the meaning of a theory, and not requiring systemic problem solving skills (Lasiani, 2017). So, teaching strategies by analogy are believed to be able to facilitate the learning process of students, but the application of this technique must pay attention to students' preconceptions and absorptions so that misconceptions do not occur (Prastowo, 2011). Misconception is caused by the analogy chosen too far with the concept that is analogous. Bridging analogy connects the concept of source problems and target problems. Bridging analogy is easier for students to understand because it makes the analogy distance to the target problem closer (Clement, 1993).

Analogy thinking uses the ability of the left brain in analytical and logical thinking, and the ability of the right brain to make reasoning, come up with ideas, and recognize patterns. The Brain Based Learning (BBL) model has the opportunity to train analogy skills because it involves maximally all the ability of students to search for and investigate something systematically, critically, logically, analytically so that they can formulate their own concepts that are learned with confidence.

Brain Based Learning also facilitates active teaching and learning processes to build knowledge through learning experiences. The experiences in the BBL model are built by creating a learning environment that challenges orchestrated immersion, creating a pleasant learning environment (relaxed allertness), and creating active and meaningful learning situations (active processing) (Gözüyeşil \& Dikici, 2014). Experiences are used to think analogies because students are 
guided to find out for themselves the similarities and inequalities of concepts from experiences that have been understood (sources concept) with the concept of physics as target concept.

One of the reference concepts that can be presented in the form of buying and selling phenomena in everyday life. The concept of buying and selling is simple and is often found even in everyday life. The reference concept was then developed to explain the target problem. The target problem is the concept of work physics and energy. Mapping source problems and target problems in accordance with relevant concepts and irrelevant concepts so as not to confuse students and cause misconceptions.

Teacher's skills in explaining the analogy to physics learning is a very important aspect of teacher activity to help students understand the concept of physics (Muchsin, 2017). Teachers can take advantage of mapping the concept of reference and the concept of target as one way to trill student analogy ability. The analogy through this buying and selling phenomenon introduces a new paradigm of physics learning to gain a broader and deeper understanding of matter with different points of view.

\section{METHOD}

This study uses a quasi-experimental method by applying the Brain Based Learning (BBL) model through the analogy of buying and selling. The subject of the research was the tenth grade students of SMAN 1 Andong Boyolali Semester II 2017/2018 Academic Year. Data collection techniques using pretest and posttest with the ability of analogy in the form of descriptions.

The draft bridge design of analogies on work and energy concepts is prepared through literature studies. The analogy bridge is designed by making a comparison map between the reference concept of the phenomenon of buying and selling and the concept of targets on work and energy. The design of this analogy bridge is used as a basis for training students' analogy skills in solving problems. If there are many similarities between the two concepts compared, then a thought analogy can be constructed. The analogy bridges that have been compiled are then validated by expert.

Data were analyzed from the achievement of the ability value of the analogy based on the stages of analogy in problem solving. The stages of analogy in problem solving as stated by Clement (1993) consist of 1) generating the analogy 2) evaluating the analogy relations, 3) understanding the analogy case, and 4) transfering findings.

The phenomenon of buying and selling as a reference concept is assumed to have been known and reapplied first before the teaching concepts are used as the target analogies. Under certain conditions, the concept of target can precede the concept of reference so that the concept of reference should still be submitted first to the student before discussing the concept of the target.

\section{RESULT AND DISCUSSION}

\section{Phenomenon of Buying and Selling as Reference Concept}

Buying and selling activities are found and performed in everyday life. Buying and selling activities such as goods purchase transactions and money storage in a bank. Buying and selling activities is a routine activity that occurs on a daily basis. Buying and selling activities is a routine activity that occurs on a daily basis. The buying and selling activities will be executed if there is agreement between the two parties to exchange goods or services with money. The definition of the concept of sale and purchase is shown in Table 1. 
Table 1. Definition of the concept of buying-selling in everyday life

\begin{tabular}{|c|c|}
\hline Concept of buying-selling & Definition \\
\hline 1. Money & $\begin{array}{l}\text { The means of exchange owned by a person or group of people as a } \\
\text { means of accumulating wealth }\end{array}$ \\
\hline 2. Rupiah & The official currency unit of Indonesia \\
\hline 3. Force of attraction & $\begin{array}{l}\text { Quality of goods as a requirement so as to attract consumers to } \\
\text { make a purchase }\end{array}$ \\
\hline 4. Purchase & $\begin{array}{l}\text { 4. Conducting transactions to transfer ownership of goods and or } \\
\text { services }\end{array}$ \\
\hline 5. Transaction & $\begin{array}{l}\text { 5. Activities that occur between two or more parties which may cause } \\
\text { changes to the financial position and ownership between the two } \\
\text { parties. }\end{array}$ \\
\hline $\begin{array}{l}\text { 6. Location of the } \\
\text { transaction }\end{array}$ & Place of doing transaction \\
\hline 7. Cash & $\begin{array}{l}\text { 7. Money (in the form of coins or banknotes) circulating in the } \\
\text { community }\end{array}$ \\
\hline 8. Items & $\begin{array}{l}\text { 8. Everything human needs to survive and to gain prosperity and } \\
\text { comfort }\end{array}$ \\
\hline 9. Transaction rate & Speed of transactions made by a person in meeting the needs \\
\hline 10. Purchasing power & 10. A person's ability to make transactions \\
\hline 11. Period & 11. The time period required for the transaction \\
\hline 12. Savings & $\begin{array}{l}\text { 12. Deposits withdrawal may only be made under certain agreed } \\
\text { conditions }\end{array}$ \\
\hline 13. Deposit system & 13. How a person in the storage in the bank with a certain amount \\
\hline 14. Deposits & 14. Client's money deposited or invested in the bank. \\
\hline 15. Profit & $\begin{array}{l}\text { 15. A number of rewards from banks to customers on deposits with a } \\
\text { certain percentage and term of deposit }\end{array}$ \\
\hline 16. Saldo & 16. Total ownership within a specified period of time \\
\hline
\end{tabular}

The definition of the concept of sale-sale described in Table 1 is used to describe the concept of reference to be used during work and energy learning. The definition needs to be explained so that students have an initial picture before doing an analogy with the concept of physics. Furthermore, students are directed to look for analogies that fit the work and energy concepts. Students need to be accompanied when making analogies and direct evaluation to avoid misconceptions.

The concept of buying and selling that is used as a reference concept has a similar nature with the concept of physics being targeted, but it should be understood that some of the concepts are also part of irrelevant nature. This suggests that the mapping of the concept of reference and the concept of targets needs to take account of the similarity and inappropriateness of the two concepts.

\section{Concept of Work and Energy}

In physics, work is defined as a force acting on an object that causes it to move. Thus, if a force acts on an object but it does not move, it is said that the force is not doing work. Some concepts that students need to understand about work and energy include:

\section{Work as energy transfer}

a. Energy is owned by the system (objects) so that objects can do work

b. Energy can be transferred from one object to another while doing work

Energy is analogized as money owned by a person. Money is used to transact in order to satisfy the interest of an item so that it can make a purchase (transfer of ownership). Money can also be transferred from the owner of the money to the recipient (eg from A to B) who needs money so that it can transact. The money transfer causes the owner's (A) money to be reduced and the recipient's money (B) becomes increased. 


\section{Work as the dot product of the F-s}

Work occurs when a force (F) is applied to the object so that the object is displaced as far as $(s)$, where $W=F \Delta x$

The work is zero when there is no displacement and when force $(F)$ and displacement $(\Delta x)$ are perpendicular to the equation $W=F \Delta x \cos \theta$

The work concept on the dot multiplication of the $F-s$ is analogous to the projection of the location of the transaction with several alternative road options. The choice of the appropriate path will likely find the location and make the transaction. Incorrect road choices will minimize the chances of a transaction. The wrong road option will make it difficult to find the location and have a chance to cancel the transaction.

\section{Work by several forces}

The total work done on an object is the amount of force applied to the object. The amount of work can be expressed by the equation

$$
W_{\text {total }}=W_{1}+W_{2}+W_{3}
$$

Enterprises by various forces are analogous to a family consisting of father, mother and two children buying goods (eg electronic goods). Transactions for the totals that occur are the sum of all transactions they make. Some analogous concepts have similar characteristics that guide students to understand the concept of targets. The concept of reference and the concept of target on the subconcept of work and energy is analogous to the concept of buying and selling as in Table 2 .

Table 2. The concept of work and energy

\begin{tabular}{lll}
\hline \multicolumn{1}{c}{$\begin{array}{c}\text { Comparison of concept } \\
\text { characters }\end{array}$} & Concept Referred & Concept Target \\
\hline Something the system has & Money & Energy \\
& Rupiah & Joule \\
$\begin{array}{l}\text { Unit } \\
\text { Work done system }\end{array}$ & $\begin{array}{l}\text { Transaction } \\
\text { Goods pulling style }\end{array}$ & $\begin{array}{l}\text { Work } \\
\text { Object style }\end{array}$ \\
& Purchase & Moving \\
& $\begin{array}{l}\text { The location of the } \\
\text { transaction }\end{array}$ & Corner \\
\hline
\end{tabular}

Mapping the concept of work and energy using buying and selling activities has some irrelevant concept properties. Some irrelevant concepts include:

1. Energy transfer occurs if no energy is lost (eg due to friction), whereas when transferring money there will be an administrative fee during the transaction process.

2. Road projections as work analogy as dot multiplication can confuse the students because the choice of a road with a certain direction does not indicate a large angle when moving goods.

Enterprises on the $F-s$ graph are analogous to transactions while surrounding the region. An irrelevant concept occurs when the same area, the transaction can be larger or smaller depending on the needs of each.

\section{Work Concepts and Kinetic Energy}

The amount of work the object does is equal to the energy change of the object. If the object is done work the energy of the body increases, for example, stationary (zero motion energy) and then 
given the work the energy of motion increases. The addition of energy that causes moving objects is an energy transfer. Things that have moved will have a motion energy called kinetic energy.

The energy-work theorem states that the work done by the resultant force acting on an object is equal to the kinetic energy changes experienced by that object $\left(W=\Delta E K=E K_{2}-E K_{1}\right)$. The energy-work theorem is written through equations

$$
W=\frac{1}{2} m v_{2}^{2}-\frac{1}{2} m v_{1}^{2}
$$

Energy is something that objects need to get things done. Each object has different capabilities in doing work at certain intervals. The ability of an object to conduct an work per unit of time is called power $(\mathrm{P})$. Some power concepts include:

1. The work performed per unit time, expressed by $P=\frac{W}{t}$

2. The force $\mathrm{F}$ to perform the displacement $(\mathrm{s})$ within a certain time interval $(\mathrm{t})$, is expressed by $P=\frac{\mathrm{F} s}{t}$

3. The force F performed on an object of a certain velocity, expressed by $P=F v$

The concept of kinetic energy and power is analogous to the availability of cash to meet the needs. The availability of cash is influenced by the number of needs and the rate of transactions. The more needs and more frequent transactions in a certain period of time the more cash that must be provided.

Power of objects to do work at a certain time interval is analogous to the buying force. Everyone has different purchasing power in making transactions for a certain period. Purchasing power can be influenced by several things, namely the number of transactions in a certain period of time, the tensile force of goods so as to buy the goods within a certain time, and the tensile force of goods resulting in the rate of transactions. The relation of the concept of kinetic energy of matter through bridge analogies as in Table 3.

Table 3. Work Concepts and Kinetic Energy

\begin{tabular}{lll}
\hline $\begin{array}{c}\text { Comparison of } \\
\text { concept } \\
\text { characters }\end{array}$ & \multicolumn{1}{c}{$\begin{array}{c}\text { Concept } \\
\text { Referred }\end{array}$} & \multicolumn{1}{c}{$\begin{array}{c}\text { Concept } \\
\text { Target }\end{array}$} \\
\hline $\begin{array}{l}\text { Something the } \\
\text { system has }\end{array}$ & Cash & $\begin{array}{l}\text { Kinetic } \\
\text { Energy }\end{array}$ \\
$\begin{array}{l}\text { Influential } \\
\text { quantities }\end{array}$ & $\begin{array}{l}\text { Items } \\
\text { The rate of } \\
\text { transactions }\end{array}$ & $\begin{array}{l}\text { Mass } \\
\text { Speed }\end{array}$ \\
& $\begin{array}{l}\text { Goods pulling } \\
\text { style }\end{array}$ & Force \\
& $\begin{array}{l}\text { Transaction } \\
\text { Purchase } \\
\text { Purchasing }\end{array}$ & Work \\
powing \\
& Power \\
& Period & Time \\
\hline
\end{tabular}

The mapping of the concept of kinetic energy and power using the buying and selling activities has some irrelevant conceptual properties. Mass is analogous to necessity. The mass is a fixed quantity whereas the needs may vary. Kinetic energy is owned by the system as mass objects move at a certain speed while cash needs to be provided to meet the needs and rate of transactions. 


\section{Work Concept and Potential Energy}

Work done by force depends solely on the initial position and the end position of the object is a conservative force. The work done by conservative forces depends only on the starting and ending positions making it easy to define potential energy. Potential energy is energy possessed by an object because of the influence of the position or position of the object. The potential energy of an object because its position satisfies the equation

$$
E_{p}=m g h
$$

Potential energy is analogous to savings or saved money. Saving is a public savings as a reserve in order to keep the need to transact in the short term. Savings are influenced by future needs (as a mass analogy), gravitational attraction type (gravity), and holding period (position or altitude).

The work done on an object is proportional to the potential energy change of the object. This is analogous to the transactions that occur affect the withdrawal of money in savings. The amount of transactions that occur is proportional to the change in the money saved.

The second form of potential energy is the elastic potential energy. Elastic potential energy can be stored in rubber bands arc, spring, spring, trampoline and others. The spring has a potential energy when stretched or pressed. Large springs force declared with $F=-k x$ The negative sign indicates that the direction of force is always opposite to the direction of the spring length change. If the spring is pulled to the right beyond the equilibrium position then the spring force is directed to the left. Conversely, if the spring is pressed to the left beyond the equilibrium position the spring force is directed to the right. Mathematically big work by the spring force expressed with

$$
W_{\text {spring }}=-\frac{1}{2} k\left(x_{2}^{2}-x_{1}^{2}\right)
$$

Potential energy in the spring is analogous to the amount of savings (savings) that are affected by the deposit system (force of deposit), initial and final deposit, and interest. Relation of potential

\begin{tabular}{|c|c|c|}
\hline $\begin{array}{l}\text { Comparison } \\
\text { of concept } \\
\text { characters }\end{array}$ & $\begin{array}{l}\text { Concept } \\
\text { Referred }\end{array}$ & $\begin{array}{c}\text { Concept } \\
\text { Target }\end{array}$ \\
\hline \multirow{4}{*}{$\begin{array}{l}\text { Something the } \\
\text { system has } \\
\text { Influential } \\
\text { quantities }\end{array}$} & Savings & $\begin{array}{l}\text { Potential } \\
\text { Energy }\end{array}$ \\
\hline & & Spring force \\
\hline & Deposits & Spring splits \\
\hline & Profits & $\begin{array}{l}\text { The spring } \\
\text { constant }\end{array}$ \\
\hline \multirow{5}{*}{$\begin{array}{l}\text { Other } \\
\text { quantities }\end{array}$} & Transaction & Work \\
\hline & $\begin{array}{l}\text { Bank without } \\
\text { profits }\end{array}$ & Conservative \\
\hline & $\begin{array}{l}\text { Bank with } \\
\text { profit }\end{array}$ & $\begin{array}{l}\text { Nonconser- } \\
\text { vative }\end{array}$ \\
\hline & Period & Time \\
\hline & $\begin{array}{l}\text { Goods pulling } \\
\text { force }\end{array}$ & Force \\
\hline
\end{tabular}
energy concepts as described in Table 4. 
Mapping the concept of potential energy using buying and selling activities has some irrelevant conceptual properties. Facts on the ground, saving is the sum of deposits and interest given. This is irrelevant to the concept of a target which only explains that there are several things that affect the magnitude of the potential energy of the spring.

\section{Concept of Mechanical Energy}

If the object only works conservative force, then the mechanical energy of the object is always fixed. This relationship is an expression of the law of conservation of mechanical energy. The amount of mechanical energy in the body can be illustrated by $E_{M 1}=E_{M 2}$

The mechanical energy of the object at each position is always fixed, which changes only potential energy with its kinetic energy. The law of conservation of mechanical energy applies also to the case of motion of an object influenced by the spring force. Students understand that energy can be altered entirely from one form to another. Mechanical energy as a result of the sum of kinetic energy and potential energy is analogous to the saldo of ownership. Saldo is an accumulation of deposits in the form of cash (kinetic energy) and savings (potential energy). If the entire saldo in the form of savings then the amount of savings to maximum while the amount of cash equal to zero. If the entire saldo is in the form of cash then the maximum amount of cash while the amount of savings equal to zero. The ownership saldo is deemed fixed as long as no additions or deductions are made. The relation of kinetic energy, potential energy and mechanical energy is analogous to Table 5 .

Table 5. Concept of Mechanical Energy

\begin{tabular}{|c|c|c|}
\hline $\begin{array}{c}\text { Comparison of } \\
\text { concept } \\
\text { characters }\end{array}$ & $\begin{array}{l}\text { Concept } \\
\text { Referred }\end{array}$ & Concept Target \\
\hline \multirow[t]{3}{*}{$\begin{array}{l}\text { Something the } \\
\text { system has }\end{array}$} & Saldo & $\begin{array}{l}\text { Mechanical } \\
\text { energy }\end{array}$ \\
\hline & Savings & Potential energy \\
\hline & Cash & Kinetic energy \\
\hline
\end{tabular}

Mapping the concept of potential energy using buying and selling activities has some irrelevant conceptual properties. The mechanical energy in each position is always fixed, but the saldo in the buying and selling activities is not fixed as it may vary according to the transaction.

Mapping the concept of reference to the phenomenon of buying and selling activities need to be tested field to determine the effectiveness of the bridge analogies used. The concept of buying and selling that is difficult to understand students can cause students have difficulty understanding the concept of the target. The application of the bridge of the analogy needs to pay attention to the learning model being implemented. Appropriate learning models can help to increase student activity in searching for conformity between the concept of reference and the concept of the target being studied. On other occasions, students can be directed to look for analogies of other phenomena already understood by students by mapping out relevant and irrelevant concepts.

\section{Achievement of Student Analogy Ability}

Achievement of students' analogy abilities is shown from the results of the pretest and posttest abilities of analogy. Pretest was conducted to determine the initial achievement of students 'analogy abilities and posttest was used to determine changes in students' analogy abilities. The average achievement of students' analogy abilities after learning is presented in Table 6. 
Eka Desianna, et al. / Phys. Comm. 3 (1) (2019) 10-20

Table 6. Average achievement of students' analogy abilities

\begin{tabular}{lcl}
\hline \multicolumn{1}{c}{ Tahapan Analogi } & $\begin{array}{c}\text { Average } \\
\text { value }\end{array}$ & Criteria \\
\hline $\begin{array}{l}\text { Generating the analogy (GA) } \\
\text { Evaluating the analogy relations }\end{array}$ & 90,74 & Good \\
$\begin{array}{l}\text { (EA) } \\
\text { Understanding the analogy case }\end{array}$ & 88,53 & Good \\
$\begin{array}{l}\text { (UA) } \\
\text { Transfering findings (TF) }\end{array}$ & 55,44 & Good \\
\hline
\end{tabular}

The average achievement of students' analogy skills as in Table 6 shows the stages of generating the analogy including good criteria, evaluating the analogy relations stage including good criteria, understanding the analogy case stage including good criteria, and transfering findings including not good criteria. Details of the achievement of the ability of the analogy are explained for each stage of the analogy carried out. Data on the acquisition of ability values for analogy at each stage as in Figure 1.

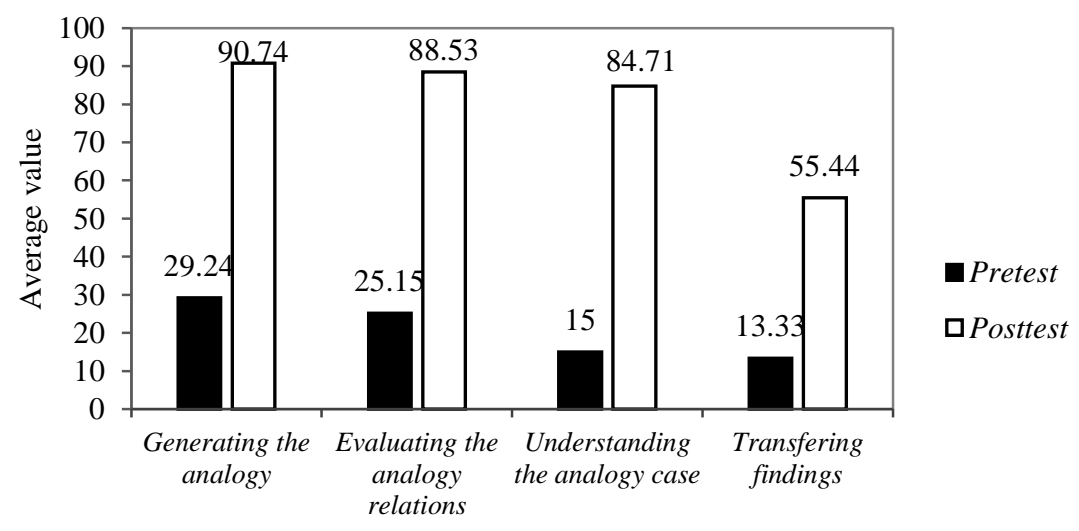

Stages of Analogy in Solving Problems

Figure 1. Average achievement of analogy capabilities

The average value of the analogy ability at the GA stage shows that students have been able to mention the concept of the source and the corresponding target concept. Before learning, some students have displayed analogy abilities and are able to mention the concept of the source and the concept of the target even though it is not yet complete. Students' answers follow the pattern of the buying and selling phenomenon which is used as an analogy. Similar results are shown at the EA stage that students have been able to relate the concept of the source and the concept of the target that has conformity. The UA stage also shows a better analogy ability because students are able to apply the source concept and the target concept to the problem to make the right conclusions. This is inseparable from the application of the BBL model that facilitates students to be active during learning. In addition, the simple analogy of buying and selling makes it easy for students to memorize important concepts on the target problem correctly.

Brain Based Learning helps students to think critically and think creatively when making analogies. The elaboration phase of BBL learning gives students the opportunity to connect neurons in the brain through discussion to investigate and analyze the problems given. This stage trains students to make their own conclusions in solving problems that trigger the ability of the analogy they have. The GA and EA stages are still dominated by students' ability to memorize source problems and interconnected target problems. This stage helps students to arrive at problem solving. 
Students easily remember source problems and target problems because of the source problems used in the form of daily experiences (the buying and selling phenomenon). According to Prihartanti et al. (2017) that in the problem solving process students need knowledge from previous experience, both from the learning experience and daily experience. BBL learning helps students maintain memory through fun learning. Brain gym treatments that are given at the beginning of learning help students focus and be ready to learn so that the analogy abilities at the GA and EA stages get better. A good analogy ability can improve problem solving abilities. This is in accordance with Wiguna's (2016) study which explains that the BBL model helps the brain work optimally so as to improve problem solving abilities.

The final stage in the ability of analogies shows a lower achievement compared to the three previous stages. The ability of analogy in the TF stage requires students to be able to determine the steps, reasons and answers to problems in the source problem and target problems appropriately. At this stage students still experience difficulties in determining the right solution of the mathematical problems presented. Students have not been able to change the concept of description into the form of mathematical concepts. This is caused by a variety of factors, ranging from the students' initial mathematical abilities that are still lacking, the analogy of buying and selling that is still inappropriate so that students feel confused in making conclusions, and choosing BBL strategies that still require improvement, especially in teaching mathematical concepts. This causes students are used to memorizing formulas to understand the concept of physics (Hartini, 2014). Nevertheless, the BBL model through the analogy of buying and selling is proven to give positive results on the ability of students' analogy to work and energy learning.

\section{CONCLUSION}

Learning through analogy is one of the alternatives offered in improving the ability of students' analogy to work and energy learning. Bridge analogy (bridging analogy) is needed so that the concept of physics is easier to understand. The bridge of analogy used in work and energy learning uses the concept of buying and selling. Mapping the concept of buying and selling and the concept of physics needs to pay attention to relevant and irrelevant concepts so as not to cause misconceptions.

The Brain Based Learning (BBL) model is applied using the bridge of sale and purchase analogy that has been compiled. The application of the BBL model through the buying and selling analogy can improve students' analogy skills. Achievement of students' analogy abilities in terms of each stage of analogy in problem solving. The average achievement of students' analogy skills at the stage of generating the analogy includes good criteria, at the stage of evaluating the analogy relations including good criteria, the understanding of the analogy case stage includes good criteria, and the transfering findings include not good criteria.

\section{REFERENCES}

Barniol and Zavala. 2014. Force, velocity, and work: The effects of different contexts on students' understanding of vector consept using isomorphic problems. Phys Rev St Phys Education 10(2): $1-5$.

Clement, J. 1993. Using Bridging Analogies and Anchoring Intuitions to Deal with Students' Preconceptions in Physics. Journal of Research in Science Teaching, 30(10): 1241-1257.

Dalaklioglu, S., Demirci, N \& Şekercioğlu, A. 2015. Eleventh Grade Students' Difficulties and Misconceptions About Energy and Momentum Consepts. International Jurnal on New Trends in Education and Their Implications 6(1): 13-21.

Fathurohman, A. 2014. Analogi dalam Pengajaran Fisika. Jurnal Inovasi dan Pembelajaran Fisika. 1(1): 74-77. 
Hartini, T. I., Kusdiwelirawan, A., \& Fitriana, I. 2014. Pengaruh Berpikir Kreatif Dengan Model Problem Based Learning (PBL) Terhadap Prestasi Belajar Fisika Siswa dengan Menggunakan Tes Open Ended. Jurnal Pendidikan IPA Indonesia, 3(1): 8-12.

Hasim W., \& Ihsan, N. 2011. Identifikasi Miskonsepsi Materi Usaha, Gaya Dan Energi Dengan Menggunakan CRI (Certainty of Response Index) Pada Siswa Kelas VIII SMPN 1 Malangke Barat. Jurnal Sains dan Pendidikan Fisika, 7(1): 25-37.

Lasiani, L., \& Rusilowati, A. 2017. Pola pemecahan masalah berdasarkan representasi siswa dalam membangun pemahaman konsep fisika. Physics Communication, 1(1): 1-7.

Masita, S., Syamsu \& Darmadi, I. W. 2015. Pengaruh Model Pembelajaran Kooperatif Tipe Investigasi Kelompok Terhadap Perubahan Konsep Fisika Siswa Kelas XI IPA di SMA Negeri 1 Marawola Pada Konsep Usaha Dan Energi. Jurnal Pendidikan Fisika Tadulako (JPFT), 3(1): 32-37.

Muchsin, \& Khumaedi. 2017. Analisis Keterampilan Mahasiswa Calon Guru dalam Menjelaskan Konsep Menggunakan Analogi pada Pembelajaran Fisika. Physics Communication. 1(1): 2333.

Prastowo, T. 2011. Strategi Pengajaran Sains dengan Analogi: Suatu Metode Alternatif Pengajaran Sains Sekolah. Jurnal Penelitian Fisika dan Aplikasinya. 1(1): 8-13.

Prihartanti, D., Yuliati, L., \& Wisodo, H. 2017. Kemampuan Pemecahan Masalah Siswa pada Konsep Impuls, Momentum, dan Teorema Impuls Momentum. Jurnal Pendidikan Teori, Penelitian, dan Pengembangan, 2(8): 1149-1159

Singh dan Schunn. 2009. Connecting three pivotal consepts in K-12 science state standard and maps of conceptual growth to research in physics education. Jurnal Physic Teacher Education. 5(2): $16-42$.

Suana, W. 2014. Mengungkap Miskonsepsi Mekanika Mahasiswa Calon Guru Fisika Semester Akhir Pada Salah Satu Universitas di Lampung. Jurnal Pendidikan MIPA, 15(1): 1-8.

Wiguna, S G A., Widiana, I W., \& Sudana, D N. 2016. Penerapan Pembelajaran Berbasis Otak Untuk Meningkatkan Kemampuan Pemecahan Masalah Matematika Siswa Kelas V. eJournal PGSD Universitas Pendidikan Ganesha. 4(1):1-11. 